\title{
THE TREND OF JUDICIAL DECISIONS IN COOPERATIVE MARKETING*
}

\author{
Frank Evans $\dagger$ and Irwin Clawson $\ddagger$
}

The rising cost of living, together with the increase in the expense of operation of farms, has focused the attention of the public on the need for greater economies in the production and distribution of products of the soil. The conviction is growing that these economies may be realized through cooperatives. It has been demonstrated on a vast scale, over a period of nearly half a century, that the growing, selling, and transportation processes by which food is supplied to the public are more effectively handled through legalized combinations of producers than by any other known means, and, as a very important part of this complicated process, the exacting demands for both quantity and quality are realized.

Every arrival in the business arena bringing with it a new idea has been compelled to justify its existence not only in practice but also under the scrutiny of the courts. Not all have survived, but the cooperative corporation has made constant progress and now is so firmly established that it has come to be regarded as a permanent part of the American economic system.

That type of litigation designed to test the validity of the cooperative is steadily decreasing, and rarely do we find, in these days, a judicial challenge to the foundation upon which these institutions are built. Occasionally, a case is found concerning some activity other than agriculture where cooperative principles are involved and by which some additional light may be reflected upon the agricultural cooperative. A good example is the Associated Press case. ${ }^{1}$ No doubt the public, as well as the bar, was surprised to find that this institution, wholly different in character from the agricultural cooperative, was treated by the Court as a cooperative organized and operating on the same principles as the agricultural cooperative. As was to be expected, the case aroused widespread interest. The government sought and obtained a conviction for violation of the Sherman Act. The association was classified as non-profit, and operated on a membership basis. Its by-laws set forth its plan of operation so far as new members were concerned, and in relation to that plan the Court said:

- The following article is based upon a similarly entitled paper presented by Frank Evans at a meeting of the American Institute of Cooperation and later reprinted with amendments and distributed by the American Farm Bureau Federation.

t Member of the Utah bar and of the American Bar Association. General Counsel, American Farm Bureau Federation, I927-r929; member of Federal Farm Board, I93I-r933. Author (with E. A. Stokdyk) of ThI LAw of Agriculturar Cooperattve Marketing (I937).

¥B.A. I914, University of Utah; J.D. I9I6, University of Chicago. Member of the Utah bar and of the American Bar Association. Attorney for several cooperatives in Utah.

${ }^{2}$ Associated Press v. United States, 326 U. S. I (1945). 
Undisputed evidence did show . . . that its By-Laws had tied the hands of all of its numerous publishers, to the extent that they could not and did not sell any part of their news so that it could reach any of their non-member competitors. In this respect the [trial] Court did find, and that finding cannot possibly be challenged, that AP's ByLaws had hindered and restrained the sale of interstate news to non-members who competed with members. ${ }^{2}$

On the question of special exemption of cooperatives under the Sherman Act, the Court added: "It is significant that when Congress has desired to permit co-operatives to interfere with the competitive system of business, it has done so expressly by legislation,"3 citing the Capper-Volstead $\mathrm{Act}^{4}$ and the Clayton Act.5

The majority opinion was delivered by $\mathrm{Mr}$. Justice Black. A vigorous dissent was voiced by Mr. Justice Roberts, who charged that the majority was making a public utility out of the Associated Press, while Mr. Justice Murphy contended that the restrictions were permissible because the members were merely trying to preserve an advantage gained by business sagacity.

It is generally believed that the issue as to exemption of agricultural cooperatives from the antitrust laws was definitely settled more than two decades ago. The Supreme Court in a unanimous opinion in the Liberty Warehouse case ${ }^{\mathbb{B}}$ made the following statement:

It is stated without contradiction that co-operative marketing statutes substantially like the one under review have been enacted by forty-two states. Congress has recognized the utility of co-operative associations among farmers in the Clayton Act, 38 STAT. 730; the Capper-Volstead Act, 42 Stat. 388; and the Cooperative Marketing Act of 1926, 44 STAT. 802. These statutes reveal widespread legislative approval of the plan for protecting scattered producers and advancing the public interest. Although frequently challenged, we do not find that any court has condemned an essential feature of the plan with the single exception of the Supreme Court of Minnesota in the above cited case.7

To the same effect were the decisions of other courts. ${ }^{8}$

Recently, however, the issue has again come into the forefront, ${ }^{9}$ and no doubt it will continue to be raised because of the very nature of the subject matter involved. For the public conscience has always been especially sensitive to restraints of trade when the particular commodities sought to be controlled have been the necessities of life. That the means of securing control were legitimate has never been enough; it was the end in itself that was condemned. Thus in very early times

Id. at 13.

* Id. at $\mathrm{r} 4$.

42 Stat. 388 (1922), 7 U.S.C. \$\$29r, 292 (1940).

s 38 STAT. 73 I (I914), I5 U.S.C. \$17 (1940).

- Liberty Warehouse Co. v. Burley 'Tobacco Growers' Co-op. Marketing Ass'n, 276 U. S. 71 (1928).

IId. at $92-93$.

${ }^{8}$ Warren v. Alabama Farm Bureau Cotton Ass'n, 213 Ala. 6r, 104 So. 264 (x925); Arkansas Cotton Growers' Co-op. Ass'n v. Brown, I68 Ark. 504, 270 S. W. 946, xxig (1925); Manchester Dairy System v. Hayward, 82 N. H. 193, 132 Atl. 12 (1926); Tobacco Growers' Co-op. Ass'n v. Jones, 185 N. C. 265 , 117 S. E. 174 (1923); Northern Wisconsin Co-op. Tobacco Pool v. Bekkedal, 182 Wis. 571, 197 N. W. 936 (1924).

United States v. Dairy Co-op. Ass'n, 49 F. Supp. 475 (D. Ore. 1943). 
the English courts nullified patents of the Crown and invalidated contracts in restraint of trade.

The point here to be emphasized, however, is that the operations of the modern cooperative corporation, even though it does restrain trade, and though it deals with the necessities of life, are not attended by any of the forbidden practices referred to in the early cases, where the parties were actuated primarily by the profit motive. The structure and the purposes of the agricultural cooperative are such that to be guided by the profit motive would be self-destructive-destructive of the institution itself. The cooperative's only guaranty of success is faithful service to those who buy and consume its products. Mere profit-making, which is the motivation of the organizations condemned for restraints of trade, is not and cannot be a motive in the true cooperative association. This was recognized as early as 1926, when the Supreme Court of North Carolina ${ }^{10}$ made this observation:

The co-operative marketing system was forced into existence to guarantee fair prices to the producers, a fair wage for labor and to prevent extortion upon the consumer....

There is no analogy between the proceedings to dissolve the great trusts which have benefited by this system, as in the Standard Oil and American Tobacco cases and others, and these associations for the protection of the producers. ${ }^{11}$

The desirability, however, of free competition in trade is only relative, and depends upon existing economic conditions. ${ }^{12}$ The early English laws on monopoly were the forerunners of the American doctrine, and were, of course, designed to meet local conditions existing at the time of their adoption. The identical doctrines have been preserved, but in their application to the larger and more complex problems of the present day, under constantly changing economic conditions, they have been found inadequate.

We do encounter relics of these ancient common-law offenses in our state constitutions and statutes, although the last of the English laws was repealed in $1844 .^{13}$ Minnesota's constitution, for example, provides that any combination designed to monopolize the markets for food products or to interfere with or restrict the freedom of such markets is a criminal conspiracy. ${ }^{14}$ The meaning of this provision as defined by the Minnesota Supreme Court ${ }^{15}$ in sustaining the constitutionality of the cooperative marketing law is of interest. The court said:

This provision of the Constitution is restrictive only.

The law is purely one of expediency, and to better the economic condition of the producers. ... It aids and harmonizes with the-constitutional provision, which is aimed

${ }^{10}$ Tobacco Growers' Co-op. Ass'n v. Jones, I85 N. C. 265,117 S. E. 174 (1923).

11. at 179 .

${ }^{12}$ See Burley Tobacco Society v. Gillaspy, 51 Ind. App. 583, 100 N. E. 89 (1912); Northern Wisconsin Co-op. Tobacco Pool v. Bekkedal, I82 Wis. 57I, I97 N. W. 936 (1924); Potter v. Dark Tobacco Growers' Co-op. Ass'n, 201 Ky. 44I, 257 S. W. 33 (I923).

1212 GEO. III, c. 71 (1772); 6 Geo. IV, c. 95 (1824); 7 \& 8 Vict., c. 24 (I844.).

14 Mrnn. Const. Art. IV, \$35.

${ }^{15}$ Minnesota Wheat Growers' Co-op. Marketing Ass'n v. Huggins, 162 Minn. 471, 203 N. W. 420 (1925). 
at those who hoard and speculate in food products, and who interfere arbitrarily and artificially with the natural flow of commerce in such products. ${ }^{16}$

A similar provision of the Utah constitution provides that any combination having for its object or effect the controlling of the price of any products of the soil is declared to be against public policy and is prohibited. ${ }^{17}$ This important measure, adopted fifty years ago, was passed by the constitutional convention after a heated debate in which practices generally approved today were condemned. The Idaho and Montana constitutions have similar provisions with reference to products of the soil. ${ }^{18}$ Other state constitutions provide against trusts and monopolies without special reference to food supplies or products of the soil, ${ }^{10}$ while the statutes of a number of states make special reference to agricultural products. ${ }^{20}$

In interpreting such provisions, in the earlier cases the courts construed them as opposing cooperative marketing organizations; in the later cases, as favoring them. But it must be borne in mind that when the earlier cases were decided there were few, if any, cooperative marketing statutes declaring, as such statutes do, a newly developed public policy. ${ }^{21}$

This definite but gradual change is most significant and far-reaching in its effects, both economically and judicially. In its early stages, progress was slow but none the less persistent, and at every step it has met with resistance. Though the United States is now generally committed to the new doctrine through the declarations of legislatures and judicial decisions, there are those who periodically raise the old issues or exercise their ingenuity to suggest new ones. An excellent example of this opposition is found in the attitude of one of the concurring judges in a Washington case ${ }^{22}$ who, though compelled to recognize the modern trend, qualified his assent by saying that he was not in accord with the repeated decisions of that court sustaining the cooperative contract, but that, since this had become the established law, the "appellants put their necks within the halter, and there is no escape."23

Another illustration, and one which is quite typical of these periodic efforts at resistance, is the present campaign on the question of taxation. It may readily be conceded that there are points of unquestionable merit in these elaborate programs of attack against the cooperatives, but generally, as time will surely demonstrate, the programs are faulty, inaccurate, and in many respects misleading and deceptive.

16 Id. at 422 .

${ }^{18}$ IDAho Const. Art. XI, 518; Mont. Const. Art. XV, \$20.

${ }^{10}$ ARIz. Const. Art. 14, \$15; Wast. Const. Art. 12, \$22; Miss. Const. Art. 7, \$198; KY. Const. 5198.

${ }^{20}$ ALA. CoDE, tit. 57, c. 6, $\$ 5106-108$ (1940); Business and Professions Code, $\$ 16720$, Deering's Cal. Code, I944; Smith \& Hurd's Ill. ANN. Stat., c. 38, par. 569 (Perm. ed. 1935); Iowa Code 55553.r, 553.ro (r946); Vernon's Ann. Penal Code, Texas, tit 19, c. 3, ARrs. 1632 to I644 (1925).

${ }^{\prime \prime}$ Cf. Liberty Warehouse Co. v. Burley 'Tobacco Growers' Co-op. Ass'n, 208 Ky. 643, 27r S. W. 695 (1925).

22 Grays Harbor Dairymen's Ass'n v. Engen, I30 Wash. 169, 226 Pac. 496 (r924).

"Id. at 498. 
The present status of the controversy is so far from final settlement that it would be futile to attempt to crystallize out of the present confusion any conclusions showing the trend on this subiect. It might be well to suggest at this point that the defense should take the same form as heretofore. There should be a strict adherence to facts. Let the case of the cooperative rest upon its own merits and avoid resort to the common practice of denouncing the opposition. If the assailants succeed in pointing out any weaknesses or errors in structure or operation, these should be corrected.

Retrospectively, a few illustrative early cases, followed by the more recent expressions of courts and legislatures, will bring into focus the well marked, step-bystep development of the law by which the present-day cooperative is authorized and governed. In an Illinois case ${ }^{24}$ in 1895 , a cooperative milk association sought to recover for milk sold and delivered to the defendants pursuant to an agreement. The statute prohibited any combination to regulate or fix the price of any commodity, and provided that no person transacting business with such a combination should be liable for the price of any commodity purchased from it. According to the by-laws of the association, some of its objects and purposes were to secure to the producer a just return for his product and to the consumer a pure and wholesome quality. The association did periodically, but not arbitrarily, establish the price at which milk was to-be sold. The court decided that the association came within the terms of the state antitrust statute, and held it to be a combination in restraint of trade, denying a recovery under the contract of purchase.

In the case of In re Grice in $18977^{26}$ a federal court, in construing a statute which prohibited all combinations in restraint of competition and exempted from its provisions "agricultural products or livestock while in the hands of the producer," said: "This statute under discussion is clearly class legislation. . . "26

Students of cooperative marketing law are familiar with the Connolly case, ${ }^{27}$ which was invariably cited as an authority opposed to exempting agricultural producers as a class from the operation of the antitrust laws. In this case, decided five years after the Grice case, the Supreme Court, in construing an Illinois statute almost identical with the law involved in the Grice case, exempting "agricultural products or livestock while in the hands of the producer," used this language:

... if combinations of capital, skill or acts . . . are hurtful to the public interests and should be suppressed, it is impossible to perceive why like combinations in respect of agricultural products and livestock are not also hurful.28

At the time this decision was written, all combinations in restraint of trade were regarded as inimical to the public interest. Because of the abstract principle set forth in the language quoted, the Connolly case became a controlling decision.

\footnotetext{
'Ford v. Chicago Milk Shippers' Ass'n, 46 Ill. App. 576, 39 N. E. 65 I (1895).

${ }^{25}$ In re Grice, 79 Fed. 627 (N.D. Texas I897).

so Id. at 646 .

27 Connolly v. Union Sewer Pipe Co., 184 U. S. 540 (1902).

${ }^{28} I d$. at 563-564.
} 
The Decorah case ${ }^{2 \theta}$ is of great interest to the farmer cooperator. Three hundred, and fifty farmers at Decorah, Iowa, engaged in raising hogs, decided to enter into a cooperative arrangement for the marketing of their product. They organized a society and for two years engaged in cooperative selling, marketing 25,000 hogs and distributing \$430,000 among their members. Their purpose was not to pile up a surplus and pay dividends, but "to establish a market where the farmers would receive for their hogs what they were worth in Decorah." At this point a hog buyer for the Chicago market brought suit against the association, complaining that this group of farmers, by their combined action, were making it necessary for him to pay more for hogs in that locality than he had paid before, and he urged those familiar doctrines of the law-restraint of trade, monopoly, and stifling of competition. The Supreme Court of Iowa upheld a permanent injunction against this little group of producers. The court, speaking through Mr. Justice Deemer, said the "plaintiff was placed at a disadvantage and could not compete with the society in purchasing hogs from its members, and the members were not free to deal with plaintiff. If they dealt with him, he either forfeited his profits, by reason of having to pay too much for his hogs, or they forfeited a part of the purchase price as a penalty for selling to another." "To our minds," said the court, "this was undue restraint of competition." 30 This was recognized as a leading case in the application of the old doctrine to producers' cooperative associations, ${ }^{31}$ but the doctrine as here applied has, under cooperative marketing statutes, been wholly overturned. ${ }^{32}$ It should not be overlooked that this association was organized under the general law. It is also worthy of note that in an earlier case, Judge Deemer, construing the antitrust statute, held that laborers might fix the price or value of their services. ${ }^{33}$

The first well-considered case announcing the doctrines to which the courts in recent decisions are committed was the Gillaspy case, ${ }^{34}$ decided by the Supreme Court of Indiana just one year prior to the decision in the Decorah case. At that time there was a sharp conflict between the two doctrines, with the weight of authority favoring the theory of the Decorah case, and there was great uncertainty whether that of the Indiana court could survive. The Gillaspy case, however, is clear and well reasoned, and stands today as one of the best considered cases of this category.

Up to that time the struggle had been largely a legal one, and the real nature

"Reeves v. Decorah Farmers' Co-op. Society, 160 Iowa 194, 140 N. W. 844 (1913).

${ }^{30} 1$ Id. at 848 .

"1 Cf. Burns v. Wray Farmers' Grain Co., 65 Colo. 425, 176 Pac. 487 (19r8).

"2f. Tobacco Growers' Co-op. v. Jones, I85 N. C. 265 , x17 S. E. 174 (1923); Washington Cranberry Growers' Ass'n v. Moore, II7 Wash. 430, 20r Pac. 773 (I921); Northern Wis. Co-op. Tobacco Pool v. Bekkedal, I82 Wis. 571, 197 N. W. 936 (1924); Minnesota Wheat Growers Co-op. Marketing Ass'n v. Huggins, 162 Minn. 471, 203 N. W. 420 (1925); Harrell v. Cane Growers Co-op. Ass'n, 160 Ga. 30, 126 S. E. 53! (1925); Dark Tobacco Growers' Co-op. Ass'n v. Dunn, 150 Tenn. 614, 266 S. W. 308 (1924); Anaheim Citrus Fruit Ass'n v. Yeoman, 5I Cal. 759, 197 Pac. 959 (1921).

"2: Rohlf v. Kasemeier, 140 Iowa I82, 118 N. W. 276 (rgo8).

"B Burley Tobacco Society v. Gillaspy, 5I Ind. App. 583, 100 N. E. 89 (1912). 
and genius of the farmers' cooperative movement was little understood. So we are led to inquire into the basis of the subsequent trend. Is it legal, or economic, or both? It is sufficient to say that basically the problem is economic, but the solution is legal, usually leading into the question of monopoly and restraints.

Although our courts followed the English decisions in determining the question of monopoly, the American people were not satisfied with limitations merely as to time and place. Americans resent bigness and its consequent influence and interference with free competition. Thus the decisions in this country deal with the broader doctrine that all contracts tending unreasonably to restrict competition, by whatever means, are contrary to public policy.

The first important application of this doctrine in this country was in the Standard Oil case, ${ }^{35}$ in which Chief Justice White traced the development of the principles of monopoly and restraint of trade in English law and found the basis for the so-called "rule of reason." The distinction between restraint of trade, the English doctrine, and restraint of competition, the later American development, must be considered if the recent decisions of American courts are to be appreciated. ${ }^{\mathbf{8 6}}$ No doubt the principles of the common law as applied to the circumstances in England which gave rise to them were well justified; but when an attempt was made to apply them to conditions vastly more complicated, operating over a great territory and applying to an economic situation which is almost wholly different, it is not surprising that these doctrines have in a measure failed to accomplish their purpose. In the Standard Oil and Tobacco Company ${ }^{37}$ cases, size and consequent influence were undoubtedly regarded as objectionable. But in the Steel Trust ${ }^{\mathbf{3 8}}$ cases the Court held that the antitrust laws offered no objection to the mere size of a corporation, even though its strength might give to it a dominating place in the industry, and that it was entitled to maintain its size and the power that legitimately goes with it, provided no law had been transgressed in obtaining it. The principles enunciated in these cases were later reflected in the Mason case, ${ }^{39}$ in which the Tennessee court said:

The mere fact that complainant [cooperative marketing association] is large and powerful, and may in the future be guilty of some one or more of these acts [coercion or suppression of competitors, arbitrarily fixing and maintaining prices, or other acts making combinations illegal], does not render it an unlawful combination or trust. ${ }^{10}$

The significance of size and its possible effect has been before the Supreme Court recently in the new American Tobacco case, ${ }^{41}$ which somewhat modifies the views expressed in the earlier cases. The prosecution there was directed against the so-called "Big Three"-American Tobacco, Liggett \& Myers, and Reynolds

\footnotetext{
"Standard Oil Co. of New Jersey จ. United States, 221 U. S. I (Igri).

"Cf. Fisher Flouring Mills Co. v. Swanson, 76 Wash. 649, 137 Pac. 144 (1913).

"United States v. American Tobacco Co., 221 U. S. I06 (IgII).

"United States v. United States Steel Corp., 25 I U. S. 417, 447 (r920).

"Dark Tobacco Growers' Co-op. Ass'n v. Mason, 150 Tenn. 228, 263 S. W. 60 (1924).

${ }^{\circ} \mathrm{Id}$. at 65.

41 American Tobacco Co., et al. v. United States, 328 U. S. 78I (I946).
} 
Tobacco. Together, according to the records, they manufactured 68 per cent of all cigarettes in 1939. Concerning this matter of size, the Court said:

Without adverse criticism of it, comparative size on this great scale inevitably increased the power of these three to dominate all phases of their industry. "Size carries with it an opportunity for abuse that is not to be ignored when the opportunity is proved to have been utilized in the past." United States v. Swift \& $\mathrm{Co}_{0}, 286 \mathrm{U}$. S. 106.

We agree with the lower courts that such actaal exclusion of competitors is not necessary to that crime [violation of the Sherman Act]. $\$ 2$

Quoting with approval from the Aluminum case, ${ }^{13}$ the Court continued:

[Defendant] insists that it never excluded competitors; but we can think of no more effective exclusion than progressively to embrace each new opportunity as it opened and to face every newcomer with new capacity already geared into a great organization, having the advantage of experience, trade connections and the elite of personnel.44

In I92I the Supreme Court decided the American Column \& Lumber case, 45 in which the legality of the so-called "Open Competition Plan," sometimes known as the "New Competition," was considered for the first time by the Court. The declared purpose of the association was to disseminate among members accurate knowledge of production and marketing conditions so that each member might gauge his market intelligently instead of guessing at it; to make competition open and above-board, instead of secret and concealed; and to substitute frank and free statements of competitors for the frequently misleading and colored statements of the buyer. The plan as operated was condemned by the Court, but in a dissenting opinion, significant because of the later attitude of the Court, Mr. Justice Holmes said:

I should have thought that the ideal of commerce was an intelligent interchange made with full knowledge of the facts as a basis for a forecast of the future on both sides. A combination to get and distribute such knowledge, notwithstanding its tendency to equalize, not necessarily to raise, prices, is very far from a combination in unreasonable restraint of trade. ...

I must add that the decree as it stands seems to me surprising in a country of free speech that affects to regard education and knowledge as desirable.18

Just four years after Mr. Justice Holmes expressed these views, in 1925, the Supreme Court decided the Maple Flooring ${ }^{47}$ and the Cement Association cases, ${ }^{48}$ in which a majority of the Court approved in principle the doctrines set forth by Mr. Justice Holmes in the American Column case. These cases certainly show a relaxation of the purpose to prevent a common understanding and a common

'Id. at 796,809 .

18 United States v. Aluminum Co. of America, Y48 F. 2d 4I6 (C.C.A. 2d 1945).

"Id. at 43I. See also State ex rel. Arn. v. Consumers Co-op. Ass'n, 163 Kan. 324, 183 P. 2d 423 (r947).

${ }^{6}$ Ameriean Column \& Lumber Co. v. United States, 257 U. S. 377 (x92x).

4- Id. at 412,413 .

"Maple Flooring Manufacturing Ass'n v. United States, 268 U. S. 563 (rg25).

“" Cement Manufacturers Protective Ass'n v. United States, 268 U. S. 588 (I925). 
enterprise, and the contention is not without merit that these decisions constitute a virtual recognition of the fact that the ancient English common-law rules of monopoly and restraint of trade which we, through our antitrust statutes, sought to perpetuate, and which the English courts had so widely extended, ${ }^{48}$ are not applicable to present-day economic conditions in America.

In 1933 a long stride was taken in the gradual development of the doctrines of restraint. In the Appalachion Coals case ${ }^{50}$ the Court was presented with the problem of a sick industry attempting to help itself. The number of persons employed in the mining and distribution of the product was large, and the need for the product was great. Yet, because of overproduction, aggravated by "distress" coal continuously thrown on the market, coupled with the existing economic depression, the situation had become desperate. Some $x_{37}$ producers, who controlled 73 per cent of the coal produced in the Appalachian region, established a common sales agency, the accused in this case. The lower court found that in the operation of the combination there was a diminished production (but sufficient for all needs), and referred to the previous surplus as a "wasteful surplus." The lower court also found that the sellers "will not have monopoly control of any market nor the power to fix monopoly prices." Chief Justice Hughes, delivering the opinion of the Court, said:

The mere fact that the parties to an agreement eliminate competition between themselves is not enough to condemn it.... A cooperative enterprise otherwise free from objection, which carries with it no monopolistic menace, is not to be condemned as an undue restraint merely because it may effect a change in market conditions, where the change would be in mitigation of recognized evils, and would not impair, but rather foster, fair competitive opportunities. Voluntary action to rescue and preserve these opportunities and thus to aid in relieving a depressed industry and in reviving commerce by placing competition upon a sounder basis, may be more efficacious than an attempt to provide remedies through legal processes.... The fact that the correction of abuses may tend to stabilize a business, or to produce fairer price levels, does not mean that the abuses should go uncorrected or that cooperative endeavor to correct them necessarily constitutes an unreasonable restraint of trade..$^{51}$

Here we have an expression of the most advanced thought of the time on the long disputed question of reasonable restraints through combination in the interest of efficiency-the lines followed by American farmers through almost half a century.

President Theodore Roosevelt, ${ }^{52}$ aware of the impending agricultural crisis, struck a prophetic chord when he said to the Country Life Commission in I9ro:

If there is one lesson taught by history, it is that the permanent greatness of any state must ultimately depend more upon the character of its country population than upon anything else. The problems of farm life have received very little consideration and the result has been bad for those who dwell in the open country, and, therefore, bad for the

\footnotetext{
4 Cf. Nordenfelt v. Maxim Nordenfelt Guns and Ammunition Co. [I894] A. C. 535.

40 Appalachian Coals, Inc. v. United States, 288 U. S. 344 (I933).

Id. at $353,360,373-374$.

"Communication to the Country Life Commission, July ro, rgro.
} 
whole nation. . . . I am well aware that the working farmers themselves will in the last resort have to solve this problem for themselves. ${ }^{63}$

This Commission in its report to the President recommended:

There must be a vast enlargement of voluntary organized effort among farmers themselves. It is indispensable that farmers shall work together for their common interests and for national welfare. If they do not do this, no governmental activity, no legislation, not even better schools, will greatly avail.64

The farmers, through societies such as the American Farm Bureau Federation, the Grange, and the Farmers' Union, became the advocates of their own cause, and they placed it before the country with such earnestness and conviction that almost all interests were converted. One of the direct results of this campaign of education was reflected in numerous decisions in which the courts took judicial notice of the agricultural emergency ${ }^{55}$ and upon that basis sustained cooperative marketing laws, affirmed membership contracts, and approved the operations of the cooperative marketing associations.

Public opinion having been thus established, it immediately began to crystallize into statutory form. In the national enactments, the change was evident in the Clayton Act, ${ }^{56}$ passed in $19 \mathrm{I}_{4}$, which provided that the antitrust laws should not "be construed to forbid the existence or operation of labor, agricultural or horticultural organizations." In I922 the Capper-Volstead Act ${ }^{67}$ was passed, providing that "farmers ... may act together in associations ... in . . . marketing . . . products." There were also acts passed by almost every state in the union which recognized cooperatives and legalized their organization and activities.

It is well to observe the effect of changing public opinion on the application of the antitrust law to farm cooperatives. Concerning this the Alabama court, 58 in upholding a contract with a cooperative marketing association, aptly said:

As a matter of fact, while some of the fundamentals of public policy will probably remain unchanged through all the ages, public policy is generally affected by the changing values of expediency; and hence a public policy which in one age prescribes [sic] certain conduct as injurious to the public welfare, may in a later age, under changed economic and social conditions, wisely and justly tolerate, if not encourage as beneficial, the identical conduct. ${ }^{59}$

A New York court, ${ }^{60}$ in upholding against a charge of restraint of trade a contract between a milk distributor and a dairy cooperative, binding the distributor

${ }^{\mathrm{s}}$ Ibid.

ss Report of the Commission on Country Life, SEs. Doc. No. 705, 6oth Cong., $2 d$ Sess. 18 (1909).

${ }^{8}$ Cf. Liberty Warehouse Co. v. Burley Tobacco Ass'n, $208 \mathrm{Ky} .643,27 x$ S. W. 695 (1925); Harrell v. Cane Growers' Ass'n, I60 Ga. 30, 126 S. E. 531 (1925); Dark Tobacco Growers' Co-op. Ass'n V. Dunn, 150 Tenn. 614, 266 S. W. 308 (1920); Warren v. Alabama Farm Bureau Cotton Ass'n, 213 Ala. 6r, 104 So. 264 (1925).

38 STAT. 73I (I9I4), is U.S.C. SI7 (I940).

${ }^{87} 42$ STAT. 388 (I922), 7 U.S.C. 529 I (1940).

warren. v. Alabama Farm Bureau Cotton Ass'n, 213 Na. 6r, 104 So. 264 (1925).

co Id. at $26 \%$.

- Barns v. Dairymen's League Co-op. Ass'n, 220 App. Div. 624, 222 N.Y.S. 294 (1927). 
to buy milk only from the cooperative and thus allegedly depriving the plaintiff of his former outlet for milk, said:

The Legislature, backed by public opinion, has determined that the state can afford to give special treatment to this class of producers. It is a question, not of technical constitutional law, but of social policy. ${ }^{1}$ prod

The Supreme Court of Kentucky, ${ }^{62}$ in a suit for a declaratory judgment concerning a contract which, it was charged, violated the antitrust laws because 75 per cent of the growers in Kentucky, Tennessee, and Indiana were subject to it, upheld the contract and said:

That all law, even constitutional law, is not static, but progressive and in step always with sound economic conditions and an enlightened public policy, recently has come to be realized clearly, if ever it may have been thought otherwise, as is attested by the highest judicial and lay utterances. ${ }^{83}$

The Indiana court, which in the Gillaspy case ${ }^{64}$ in 1912 pioneered the trend toward upholding marketing cooperatives against the charge of restraint of trade, fourteen years later reaffirmed its stand ${ }^{65}$ and said:

The rule of reason must be applied in determining whether a contract is in restraint of trade and whether it creates a monopoly. ... "There must be an unreasonable or undue restraint of trade ... [such] as is detrimental to the public interest." 86

And the court continued that it "would be turning the wheels of progress backward to hold such contract in restraint of trade ..." ${ }^{\text {B7 }}$ when the purpose was to promote orderly marketing in the interest of the producers and the public.

Finally, after many courts had distinguished their cases from the Connolly case $^{68}$ the Supreme Court in I 940 overruled that terror of the cooperative lawyer . during the early decades of this century, saying:

Connolly's case has been worn away by the erosion of time, and we are of the opinion that it is no longer controlling. ${ }^{69}$

It would certainly appear that cooperatives have passed from the least favored position to a place of equality in most respects with other marketing agencies in the sight of the law. In one recent case, ${ }^{70}$ a court has taken a position well in advance of that which might have been expected when the struggle for equality first began. There a cooperative dairy was indicted for violation of the Sherman Act. The court held that the cooperative was, by the Clayton Act, granted immunity from the operation of the antitrust law. After reviewing the trend of de-

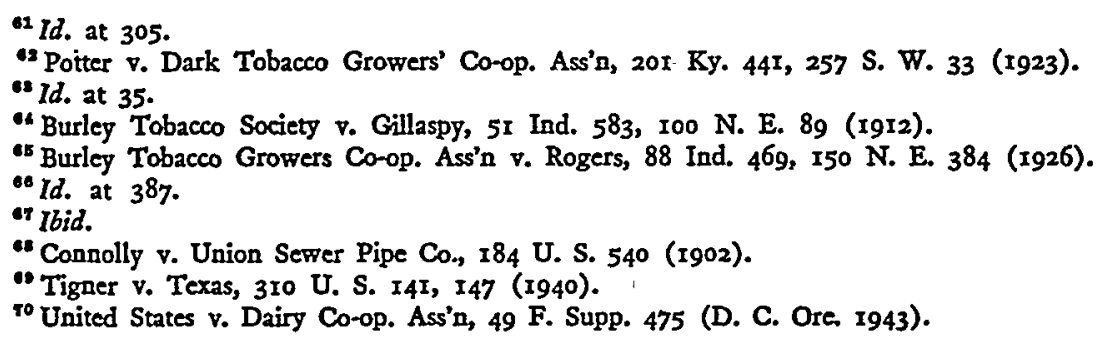


cisions on the labor clause in the Clayton Act and the apparent reluctance of "antilabor" courts, as described by this judge, to accord to labor the exemption granted by the Clayton Act, and drawing the conclusion that this attitude of the courts resulted in the Norris-LaGuardia and the Wagner Acts, the court said:

I am asked to hold that under certain circumstances, even when acting solely in its selfinterest and not in concert with others, a farmer's cooperative can be punished as a monopoly. ...

It may be that the acts of the defendant co-operative in this case, tested without regard to the provisions of the Clayton Act, are monopolistic in character. I have not given serious thought to that question for it seems to me that when Congress said cooperatives were not to be punished, even though they became monopolistic, it would be as ill-considered for me to hold to the contrary as were some of the early labor decisions. . . . .11

One recently decided case ${ }^{72}$ further emphasizing this continuing trend favorable to cooperatives may well be questioned, however. There a third party sued the cooperative for a personal injury. It was held that the company was not liable in tort because it was a non-profit organization and hence, reasoned the court, quasi-public. No other case, so far as we know, has appeared which follows this reasoning. That is not surprising, for it will be conceded that there is a vital difference between a cooperative and a charitable or quasi-public corporation such as a hospital or a taxing district.

The Kentucky court, in 1935 in the $H y$-Grade Dairies case, ${ }^{73}$ involving a similar question of law, did hold the cooperative liable in tort. In the course of the tugof-war for the milk, the court declared the cooperative dairy liable for stopping a competitor's truck and removing all milk therefrom when only part came from members under contract to deliver milk to the association.

Antitrust laws have been passed generally by the states and by the national government. ${ }^{74}$ The effect of such legislation has been limited, however, particularly in state courts, because it has been repeatedly held that these statutes were mere reenactments of common-law principles and did not have the effect of enlarging the doctrines of the common law..$^{75}$ The exemption of labor and agricultural organizations contained in the Clayton Act has been thought of dubious value ${ }^{76}$ and up to the present time the provisions of the Capper-Volstead Act, ${ }^{77}$ passed in 1922, legalizing farmers' cooperative associations for the transaction of interstate and foreign busi-

7 Ibid.

${ }^{72}$ Arkansas Valley Co-op. Rural Electric Co. v. Elkins, 200 Ark. 883, 14I S. W. 2d 538 (x940).

72 Fy-Grade Dairies v. Falls City Milk Producers Ass'n, 26r Ky. 25, 86 S. W. 2d r046 (1935).

"See Sherman Act, 26 STat. 209 (1890), as amended, I5 U.S.C. 5I (r940); Clayton Act, 38 Star. 730 (1914), 15 U.S.C. \$12 (I940); Federal Trade Commission Act, 38 STAT. 7I7 (1914), as amended, 25 U.S.C. $\$ 41$ (I940).

${ }^{35}$ Cf. Standard Oil Company of New Jersey v. United States, 221 U. S. I, 51 (Igrr); Cumberland Tel. \& Tel. Co. v. State, roo Miss. 102, 54 So. 670 (rgrr).

${ }^{20}$ Cf. Paine Lumber Co. v. Neal, 244 U. S. 459 (rgr7); Duplex Printing Press Co. v. Deering, 254

U. S. 443 (rg2r). But $f$. the Dairy Co-op. case, supra note 70.

${ }^{72} 42$ STAT. 388 (1922), 7 U.S.C. S29I (1940). 
ness, have not been refined by judicial construction except in the Borden case ${ }^{78}$ and perhaps in the Elm Spring case. ${ }^{79}$

In the Borden case, further indications of the restrictions applicable to cooperatives under the restraint-of-trade rule are found. There a cooperative dairy and a number of distributors and labor unions united to control the price of milk in Chicago. The decision revolved largely around the Capper-Volstead Act rather than the Clayton Act. The district court made an order of dismissal, relying upon the Agricultural Marketing Act ${ }^{80}$ and upon the premise that the Capper-Volstead Act legalizes price-fixing and to that extent modifies the Sherman Act. But the Supreme Court refused to permit so broad an exemption, and said:

The right of these agricultural producers thus to unite in preparing for market and in marketing their products and to make the contracts which are necessary for that collaboration, cannot be deemed to authorize any combination or conspiracy with other persons in restraint of trade that these producers may see fit to devise. ${ }^{81}$

The Court observed that the conspiracy charge was not directed against the formation of an association of producers to market their respective crops, but rather against a conspiracy with a majority of the distributors and labor unions to maintain artificial prices, and that such a combination finds no justification in the Capper-Volstead Act. The Court further held that the cease-and-desist orders of the Capper-Volstead Act are not a substitute for criminal proceedings under the Sherman Act.

A possible inference from the Borden case would be that any act of the farmer cooperative to control prices would be tolerated if the cooperative did not conspire with other groups to effect its purpose. This would accord with the first and, so far as has come to our attention, the only decision in a prosecution by the Federal Government against a cooperative on the charge of enhancing prices, where the cooperative was not combining or conspiring with other groups but was acting alone. ${ }^{82}$ As pointed out above, this was a district court decision only and immunity was granted under the Clayton Act rather than the Capper-Volstead Act.

In the Elm Spring case the reference to the Capper-Volstead Act was dictum, but the federal district court observed that the purpose of the Act was to give cooperatives exemption from the effect of the Sherman Act. ${ }^{83}$

A field to which cooperatives might look for light on the interpretation of the Capper-Volstead Act is that created by a fishermen's law ${ }^{84}$ passed in 1934. The two statutes are identical except that one refers to farmers and the other to fishermen, and the cease-and-desist orders are issuable by different cabinet officers. Two

\footnotetext{
78 United States v. Borden Co., 308 U. S. I88 (r939).

${ }^{70}$ United States v. Elm Spring Farm, 38 F. Supp. 508 (D. Mass. I94r).

${ }^{\circ}$ 5o STAT. 248 (I937), 7 U. S. C. $\$ 671$ (I940).

81 United States v. Borden Co., supra note 78, at 204-205.

s2 United States v. Dairy Co-op. Ass'n, supra note 7o.

'United States v. Elm Spring Farm, supra note 79, at $5 \mathrm{Ir}$.

" 48 STAT. 1213, $121_{4}$ (1934), I5 U.S.C. $\$ \$ 521,522$ (1940).
} 
cases $^{85}$ have been decided under this Act, both of which reflect an attempt by fishermen to "corner" their respective markets. In both cases the court held the action to be illegal.

There are new trends developing where membership is recognized as the right of an individual and not a privilege conferred by the association. This was hinted at in the Associated Press case. But the decisions on this aspect are found in labor cases rather than in those involving cooperative marketing associations. While there are some recent cases ${ }^{86}$ holding that a closed shop is not compatible with a union which refuses equal membership to all, there is another late decision ${ }^{87}$ where the contrary doctrine was applied. The issue of monopoly of the labor field was the basis of the decisions which held that membership is a right and not a privilege.

A late case which attracted widespread attention because of the nature of the attack and because of the great size and extended operations of the association is that of the Consumers Co-operative Association, ${ }^{88}$ usually referred to as the C.C.A. The attorney general of Kansas (the domiciliary state) brought quo warranto proceedings against the cooperative seeking its dissolution. This corporation is a supply cooperative engaged in domestic and foreign trade on a large scale. It shipped overseas three million gallons of motor oil. It had exchange agreements with all the major and independent oil companies, owned and operated 450 oil wells, four oil refineries, canning plants, lumber mills, soybean plants, paint factories, and printing plants. The court rejected the contention that the association had exceeded its authority, denied the petition for dissolution, and held that the ownership and operation of oil wells, refineries, pipe lines and other properties was merely incidental to the "manufacturing and furnishing of farm supplies" as authorized by the statute. While the dominant issue in this was whether the corporate activities were ultra vires, the question of the right of C.C.A. to admit non-resident corporations as members was raised. The court approved this practice in the face of what appeared to be a contrary restriction in the statute.

At first view, it is difficult to recognize this vast and varied operation as a farmers' cooperative, but the mere fact that it is not typical of such organizations does not necessarily mean that these operations are beyond its legitimate authority so long as it is serving the interests of those for whom it is authorized by statute to act. It would, therefore, be difficult to reach any conclusion other than that arrived at by the court. It is the nature and not the extent of the operations which is the test of validity.

In view of the developments to the present time, it may be said that the day of decisions such as those in the Decorah, the Grice, and the Connolly cases is

\footnotetext{
"s Hinton v. Columbia River Packers' Ass'n, I3x F. 2d 88 (C.C.A. 9th 1942); Manaka v. Monterey Sardine Industries, 4 I F. Supp. 53 (S.D. Cal. 194I).

"James v. Marinship Corp., 25 Cal. 2d 72I, 155 P. 2d 329 (1944); Betts v. Easiley, 16I Kan. 459, I69 P. 2d 83x (I946); Williams v. International Brotherhood, 27 Cal. 2d 586, I65 P. ad 903 (1946).

"Tlark v. Curtis, 7r N.Y.S. 2d 55 (Sup. Ct. N. Y. 1947).

"State ex rel. Arn v. Consumers Co-op. Ass'n, I63 K2n. 324, 183 P. $2 d 423$ (1947).
} 
past. Necessary controls exerted by cooperatives on the movement of farm products to prevent gluts and shortages, with their attendant fluctuations in prices, are uniformly approved. To accomplish this purpose, these organizations are expressly exempted from the provisions of the Sherman Act, and there is now no reluctance on the part of the courts in recognizing and upholding the exemption.

It is clearly evident that the farmers' cooperatives have made a distinct advance toward a position of equality with other businesses in our national economy.

In the process of cooperation, competition will still be found; not mere personal competition-the type of competition that depends upon cunning in disposing of the product-but rather competition in the quality of the product. Salesmanship is secondary. The selling effort has been put into quality production and begins on the farm. Cooperation involves pooling and commingling, and the inferior product is automatically penalized, creating the strongest incentive for excellence.

The observation is frequently made by our courts and others that our economic system is based upon competition; that "Competition is the Life of Trade." Our economic system under this better form of business rivalry may yet be based upon cooperation, and the time may come when our familiar commercial maxim will take the form, "Cooperation is the Life of Trade." 